\title{
Changing Land Use, Disaster Risk and Adaptive Responses in Upland Communities in Thailand
}

\author{
Malin Beckman $^{1}$, Junko Mochizuki ${ }^{2}$, Sopon Naruchaikusol ${ }^{3}$
}

Received: 22/11/2013 / Accepted: 22/11/2014 / Published: 01/06/2015

\begin{abstract}
This paper is based on qualitative fieldwork in 4 villages in northern Thailand in 2012-2013. The study focuses on the interaction between socio-economic development and climate related risk. We study local perceptions of the impacts of climate related risks and responses to these risks. The study is guided by the Forensic Investigation of Disasters (FORIN) framework with i) a critical cause analysis to identify dynamic drivers of disaster risk and ii) scenario analysis to identify disaster risk reduction (DRR) and climate change adaptation (CCA) options. Changes in livelihood strategies have been coinciding with an increase in climate related risk during the past decade, including the increased occurrence of flash floods, landslides and drought, as perceived by interviewees. In common for all villages are that policies of state-managed forest protection leave upland communities with too little land for production and fallows, leading to disaster prone cultivation on marginal lands. We argue that national policies toward upland communities tend to reinforce land use and livelihood strategies that increase disaster risk. There is need for more integrated forms of land use, like agro-forestry, to enable a combined focus on environment- and livelihood objectives in support of climate change adaptation.
\end{abstract}

Key words: Disaster risk, land use, uplands, Thailand, climate change adaptation, livelihoods

\section{INTRODUCTION}

This study focuses on changing land use, natural resources management and livelihoods in the uplands,

\footnotetext{
${ }^{1}$ Stockholm Environment Institute - Asia and Swedish University of Agriculture Sciences, Stockholm, Sweden.

Email: Malin.Beckman@slu.se

2 International Institute of Applied Systems Analysis, Laxembourg, Austria

3 Stockholm Environment Institute - Asia and Bonn University, Germany

*Corresponding Author
} 
aiming to understand how socio-economic factors interact with climatic factors to influence disaster risk, vulnerability and adaptation ${ }^{4}$. As an entry point, we take the severe flooding that affected Northern, Northeast, and Central Thailand in 2011, affecting both upland and lowland areas. The floods caused widespread damage in many sectors, both urban and rural. The flooding of Bangkok received the most media attention, and a major part of the public debate in Thailand has centered on how to best protect the low land and cities through infrastructure protection, water management, and forest replanting. However, less attention is given to how floods affect people in the upland areas. Instead, the upland population is often presented as culprits, and forest degeneration is often blamed for both floods and drought (Forsyth and Walker 2008). Also Lebel et al. (2009) find a bias in public attention and policies regarding flood mitigation, in which floods are blamed on land use changes in the upland watershed areas, with reforestation prescribed as the solution. After the 2011 floods in Thailand, the government announced a new major reforestation program, in which they are planning to plant 800 million trees (Ministry of Interior 2013). Given this suggested bias in public perspectives of flood mitigation our research explores the dynamics of disaster risk from the perspective of upland communities. How are floods perceived by upland households? How do they perceive the relation between land use and disaster risk? What are their ideas for risk reduction and adaptation? The study adopts the Forensic Investigation of Disasters (FORIN) framework with i) a critical cause analysis to identify dynamic drivers of disaster risk and ii) scenario analysis to identify disaster risk reduction (DRR) and climate change adaptation (CCA) options. The study is partly conducted in response to a call from the IRDR program (Integrated Research on Disaster Risk), to conduct case studies contributing to knowledge on socio-economic factors influencing the impact of disasters.

\section{THEORETICAL AND METHODOLOGICAL BACKGROUND-THE FORIN FRAMEWORK}

The FORIN framework is motivated by the following question that seeks to understand the current trend of rising disaster risk around the globe: "why, when so much more is known about the science of natural events, including extremes, and when technological capacity is so much stronger, are large-scale and even small- and medium-scale disasters apparently becoming more frequent and the losses continuing to increase at a rapid rate? (IRDR, 2011; White, Kates, \& Burton, 2001) . The FORIN methodology consists of four distinct approaches: critical cause analysis, meta-analysis, longitudinal analysis and scenarios of disasters. Some of these approaches overlap with other widely used conceptual models of disaster analysis such as the "Pressure and Release model" of Wisner et al. (2004) in that it attempts to identify root causes of social vulnerability and its interaction with prevalent local hazard conditions. Instead of simply identifying physical and social conditions that make communities vulnerable--be it poor land-use planning and the lack of sound building standards--the FORIN approach strives to answer the less addressed questions of 'how and why decisions were made and management options chosen (IRDR 2011 p8).' In doing so, it encourages the use of participatory research which crosses the disciplines of natural and social sciences as well as that of research and practice. In essence, FORIN calls for independent research that are conducted at arm's length from key stakeholders and official agencies that delves into the systemic issues of risk creation and vulnerability. The framework offers a set of methodologies that are built around four hypotheses, which explain the existing gap in DRR (table1). The critical cause analysis helps us to discuss the relevance of these factors in the chosen context. This study also conducts participatory scenario analysis to identify potential disaster risk reduction (DRR) and climate change adaptation (CCA) measures (for more information on the FORIN methodology, see IRDR

\footnotetext{
${ }^{4}$ The findings presented in this paper are elaborated in the report "Disaster response and adaptive capacity of upland communities in the face of increasing climate risk." (Naruchaikusol, Beckman, Mochizuki 2014)
} 
2011).

Table 1: FORIN Hypothesis*

\begin{tabular}{|l|l|}
\hline $\begin{array}{l}\text { FORIN } \\
\text { Hypothesis }\end{array}$ & \multicolumn{1}{c|}{ Contents } \\
\hline $\begin{array}{l}\text { Risk Reduction } \\
\text { Hypothesis }\end{array}$ & $\begin{array}{l}\text { New and more probing research and understanding of the reasons for growth in public } \\
\text { vulnerability and wider exposure would enable and stimulate improved disaster risk } \\
\text { reduction. This is contingent upon greater accountability, visibility and transparency of } \\
\text { risk reduction processes being employed }\end{array}$ \\
\hline $\begin{array}{l}\text { Integration } \\
\text { Hypothesis }\end{array}$ & $\begin{array}{l}\text { New and more integrated and participatory research is required to yield more useful and } \\
\text { effective results }\end{array}$ \\
\hline Responsibility & $\begin{array}{l}\text { Responsibility for the continued growth in vulnerability and exposure is locally specific } \\
\text { and diffuse over individuals, organizations, jurisdictions, and over time. This diffuse } \\
\text { responsibility is not something planned or methodically organized but has simply evolved } \\
\text { or grown up in this way. It is now postulated that more precise identification and } \\
\text { structuring of responsibilities, especially if these responsibilities can be made visible and } \\
\text { transparent, could contribute significantly to disaster risk reduction }\end{array}$ \\
\hline $\begin{array}{l}\text { Communication } \\
\text { Hypothesis }\end{array}$ & $\begin{array}{l}\text { The knowledge that exists about disaster risk reduction has not been communicated } \\
\text { effectively. This is because the intended recipients are unaware of the insights or } \\
\text { alternatively are resistant to the knowledge and information and may feel threatened by it }\end{array}$ \\
\hline
\end{tabular}

*Source: IRDR (2011)

The FORIN framework was selected as a conceptual basis because of its ability to trace the root causes of disaster risk within the larger institutional- and implementation gaps that often hinder the successful application of DRR knowledge. We use the definition of vulnerability, which is composed of exposure, sensitivity and capacity to cope and recover (Wisner et al. 2004). While the FORIN framework focuses on disaster risk reduction, it also shares broader perspectives of vulnerability and resilience to climate related risk. Therefore it was deemed appropriate to apply its framework for forward-looking analysis regarding the climate change adaptation needs of communities. ${ }^{5}$ Lebel et al. (2009) and Adger \& Brown (2009) stress the need to understand how environmental, social, political or economic processes are affecting the abilities of communities to cope with disaster risk. Lebel et al. (2009) study how changes in flood regimes coincide with, and interact with the social vulnerability arising from economic development. Davies et al. (2009) and Cutter et al. (in IPCC 2012) emphasize the need to address the structural factors influencing the ability of local people to undertake necessary measures to protect themselves, and the feasibility of adaptive shifts in livelihood strategies. In line with this we study local perspectives on adaptation to increasing climate risk, primarily at village level, but also at- local government level, and discuss how policies and institutions enable and constrain the realization of such adaptations. Our focus is on the adaptive capacity of the community in terms of the institutional 'space' to act and adapt, as perceived by

\footnotetext{
${ }^{5}$ We follow UNISDR (2009) in looking at climate related risk as including both extremes and variability. Not only disasters, but also frequent smaller losses can lead to significant livelihood impact. The UNISDR also emphasizes the importance of looking at the impacts of frequent low level losses.
} 
the villagers. We use the perspective on adaptive capacity suggested by Nelson et al. (2007), where the focus is on the characteristics of the context that facilitate flexibility in resource use, diversity of livelihood options and decision-making structures, and thus enable or constrain adaptation to change and shocks. We build on this perspective, when discussing how policies and institutions governing tenure rights and access to resources change the preconditions vital for risk management and adaptation.

\section{STUDY SITES AND FIELDWORK METHODS}

Case studies were conducted in two villages in Pua District, Nan Province and two villages in Om Koi District, Chiang Mai Province. The sites were selected based on the following criteria: They are situated in the uplands of the main river watershed system in Thailand, i.e. tributaries to the Chao Phraya River. These areas are in focus in the ongoing debate in Thailand regarding causes and impact of flood disasters. One upstream and one downstream village from each district were selected (Table 2). Mae Larn Noi village lies approximately five kilometers upstream of Soplarn village in Om Koi district; and Pang Yang village lies three kilometers upstream of Hua Nam village in Pua district. All four villages can be considered to be upland villages. The downstream villages have previously had slope land cultivation as their main livelihood, but have transferred most of their agriculture to paddy land along the rivers during the past decades. Thus, the site selection served the aim to get perspectives both from villages with access to agriculture on river banks (downstream) as compared to villages dependent on slope land agriculture (upstream). All villages are located in, or adjacent to, Forest Reserves or Forest National Parks, and are inhabited by ethnic minority groups. According to interviews with local government officers, the main natural hazards in the area include: i) landslides; ii) flash floods; and iii) strong winds, in the order of perceived risk. ${ }^{6}$ Results from village level interviews suggest that climate related stresses also include the sedimentation of waterways and paddies, drought, insect attacks, and cold spells.

The villagers' perspectives on the following issues were explored:

- How livelihoods, land use and climate related hazards have been changing over the past 10 years.

- Perspectives on how policies and institutional conditions influence livelihood options.

- Responses to climate related hazards and efforts to improve livelihoods.

- Ideas for adaptation and livelihood development under adverse climate change.

- Implications for policy and institutional change.

We conducted semi-structured interviews and focus group discussions with male and female representatives of households, community leaders, staff of government administration at sub-district, district and province level. In each village, 10-15 households were interviewed individually, while another 10-15 people participated in the group discussions. The village head in each village referred us to maps of the village showing the location of households. The village head guided us regarding the household's wealth status, livelihood and exposure to hazards, as a basis for the selection of around half of our sample. We selected households in order to get a spread of different socio-economic status, i.e. better-off and poor households, female headed and male headed households, young and old, households

\footnotetext{
${ }^{6}$ Interview with TAO (the Tambon Administrative Organizations) officers in Phu Ka subdistrict, Pua district, Nan province, September 2012 and officers in Yang Piang subdistrict, Om Koi district, Chiang Mai province November 2012.
} 
with mainly agricultural income and households with diversified income sources. Most of the households selected had been exposed to hazards (e.g. flash floods, landslides, drought) The village head did not suggest households to us, he only provided information about the different households, which we used in order to make a selection. Apart from the households thus selected, we also interviewed people who we met while we walked around the village. The method of selecting households was thus not random, but we were purposefully seeking to get input from villagers with a diverse range of livelihoods and socioeconomic status. We aimed to get different perspectives regarding villagers' experience of hazards and their ideas for adaptation. This method of sampling has been described in Miles and Huberman (1994).

Household interviews were conducted at their home, often with both husband and wife taking part. In around $1 / 3$ of the interviews, only the woman of the household took part. A focus group discussion was held with the Women's Group in Mae Larn Noi village (8 out of 20 women took part) because they were having a meeting on that day anyway. Participants in the focus groups were otherwise selected in the same way as the households to be interviewed, to provide a spread of different interests and experiences in relation to the hazards. A focus group consisted of 8-10 people, who discussed around a map of the village and a time line, focusing on hazards and stresses, consequences of these, and ideas for adaptation from a village perspective, rather than household perspective.

Interviews were conducted by all three authors of this paper. Approximately 35 percent of the interviews were conducted by the Thai author, in Thai language. 15 percent were conducted by the Thai author with interpretation from Karen language to Thai. Approximately 50 percent were conducted by the non-Thai speaking authors, with interpretation to English (from both Thai and Karen language). The group discussions were conducted in Thai language, led by the Thai author. The non-Thai speaking authors took part and got simultaneous interpretation. The interviews and group discussions were recorded, in order to be able to check afterwards whether the interpretation had been correct. Detailed notes were made during the interviews and group discussions. These notes were the basis for 'manual' analysis, following the Data Analysis Spiral described by Creswell (1998), i.e. as an iterative process of reading through the data (many times), categorizing responses, identifying patterns and responses diverging from the pattern, summarizing, obtaining feedback on the summaries, representing the data case by case, as well as by subject and themes across the cases, making interpretive propositions, which were presented for feedback etc. We did not use a computer program for analysis, both because the size of the data was possible to handle manually, and because the interview responses were expressed in many different ways, as the interviews were 'semi-structured'. Responses that occurred frequently were compiled and presented back to the villagers at feedback meetings, in order to verify our interpretations of the data. In this process the data was categorized in terms of villagers' experience of hazards, villagers' views on factors influencing vulnerability and adaptive capacity respectively, and villagers' views on changes required. These feedback meetings were organized with 10-15 villagers (around one third of whom were people we had not previously interviewed) in each village, during which we presented our findings and interpretations, and invited responses from the group. The group also gave comments regarding policy implications and institutional support. As in the focus groups, the aim was to get a picture of the experiences of the village as a whole. The analysis in this paper focuses on the changing conditions that the villages face and ideas of adaptation primarily concerning village level. We recognize that vulnerability and adaptive capacity are also socially differentiated within the villages, but that analysis will be the subject of another paper.

\subsection{Case study villages}

Soplarn village is located downstream of Mae Larn Noi village. The village head explains to us that the village settled here 70 years ago in response to government sedenterization policies, but they had lived in this area for at least 150 years. He further explains that they started giving up rotational cultivation in 
1995, letting the land regenerate back to forest permanently. He says the villagers voted to give up that land. Instead they manage it as community forest. Part of the forest, around the water source, is protected, while other forest can be used for taking timber for construction work in the village. All villagers have paddy land along the river for subsistence production of rice, and slope land fields of tomato, chili, cabbage etc.

Table 2. Characteristics of Selected Villages

\begin{tabular}{|c|c|c|c|c|}
\hline & $\begin{array}{c}\text { PangYang village, } \\
\text { Pua district, Nan } \\
\text { province } \\
\end{array}$ & $\begin{array}{c}\text { Hua Nam village, } \\
\text { Pua district, Nan } \\
\text { province } \\
\end{array}$ & $\begin{array}{c}\text { Mae Larn Noi village } \\
\text { Om Koi district, Chiang } \\
\text { Mai } \\
\end{array}$ & $\begin{array}{c}\text { Soplarn village } \\
\text { Om Koi district, Chiang } \\
\text { Mai } \\
\end{array}$ \\
\hline $\begin{array}{l}\text { Site } \\
\text { character- } \\
\text { istics }\end{array}$ & $\begin{array}{l}\text { Lua and Lahu people. } \\
83 \text { households } \\
\text { Upstream village. } \\
\text { Located in Doi Phu } \\
\text { Kha National Park. } \\
\text { Hill rice on slopes, } \\
\text { rotations of 3-5 years. } \\
\text { Paddy rice on terraces. } \\
\text { Hybrid maize on slope } \\
\text { land, as main cash } \\
\text { crop. } \\
\text { No land titles. } \\
\text { Community forest. }\end{array}$ & $\begin{array}{l}\text { Thai Yai people. } \\
144 \text { households. } \\
\text { Downstream village. } \\
\text { Households have land } \\
\text { titles for agriculture } \\
\text { land. Forest land is } \\
\text { part of Sila Laeng sub- } \\
\text { district community } \\
\text { forest. } \\
\text { Paddy rice for food. } \\
\text { Garlic, chili and onion } \\
\text { as cash crops. } \\
\text { Hill land orchards. } \\
\text { Community forest. }\end{array}$ & $\begin{array}{l}\text { Karen people. } 44 \\
\text { households } \\
\text { Upstream village. } \\
\text { Located in Mieng Ajo } \\
\text { Forest Reserve. } \\
\text { No land titles. } \\
\text { Hill rice for food. } \\
\text { Rotations of 10-15 } \\
\text { years. A little paddy on } \\
\text { terraces. } \\
\text { Tomato as main cash } \\
\text { crop. } \\
\text { Community forest. }\end{array}$ & $\begin{array}{l}\text { Karen people. } 213 \\
\text { households. } \\
\text { Downstream. } \\
\text { Located in a Mieng } \\
\text { Ajo Forest Reserve. } \\
\text { No land titles. } \\
\text { Paddy rice for food. } \\
\text { A little hill rice. } \\
\text { Tomato as main cash } \\
\text { crop. } \\
\text { Also income from } \\
\text { cattle and weaving. } \\
\text { Community forest. }\end{array}$ \\
\hline $\begin{array}{l}\text { Experience } \\
\text { of hazards }\end{array}$ & $\begin{array}{l}2011 \text { flash floods: } \\
\text { Landslides affected } \\
\text { maize fields of } 8 \text { hh. } \\
\text { Landslides damaging } \\
\text { forest and roads. } \\
\text { Loss of water pipes. } \\
\text { Frequent heavy rains } \\
\text { and strong winds. Lack } \\
\text { of water during dry } \\
\text { season since } 2008 .\end{array}$ & $\begin{array}{l}\text { Flash floods 2011: } 4.8 \\
\text { ha of paddy land lost. } \\
\text { Irrigation } \\
\text { infrastructure } \\
\text { damaged. Two houses } \\
\text { damaged by landslide. } \\
\text { Flash floods 1996, } \\
\text { 2010, 2011, 2012. }\end{array}$ & $\begin{array}{l}\text { Flash floods 2011: } \\
\text { landslide killed village } \\
\text { head and destroyed his } \\
\text { house. } \\
\text { Heavy rains. Longer } \\
\text { dry periods. }\end{array}$ & $\begin{array}{l}\text { Lost } 50 \text { percent of } \\
\text { paddy land in flash } \\
\text { floods } 2004 \text { and 2010, } \\
\text { which also damaged } \\
\text { irrigation } \\
\text { infrastructure and } \\
\text { bridges, and swept } \\
\text { away pipes. }\end{array}$ \\
\hline
\end{tabular}

\section{FIELDWORK RESULTS}

\subsection{Villager experiences of climate related hazards and stresses}

Fieldwork results suggest that flash floods and landslides have threatened lives and livelihoods in all four villages. Downstream villages, in particular, are impacted by flash floods. Hua Nam village 
experienced severe flash floods in 1996 and 2011, which, in the latter year, flooded the residential area, destroyed 5 hectares of paddy land and caused damage to the village's irrigation dam (i.e. a small scale reservoir). Two houses were destroyed by landslides. The irrigation dam was repaired after the floods 2011, but broke again in smaller floods 2012. The reliance on the dam, and the frequent damage to it, is a major concern for the farmers, according to the interviews and group discussions ${ }^{7}$. Soplarn Village, located at the intersection of the Mae Ha, Mae Lan and Mae Tun rivers, has been regarded as a favorable location for farming. However, two major flash floods occurring in 2004 and 2010 has reduced the village's paddy land by almost 50 percent, according to the Village Head. Interviewed households described how the force of the water eroded the riverbanks and carried forest debris and sediment settling on the fields. The villagers further reported how the sediment carried by the flood obstructed the river's usual course, threatening the village's residential areas with riverbank erosion. Mrs S used to grow paddy rice on the riverbank. While standing behind her house, she described to us how the river had taken 10 meters of land at this point and comes closer to her house every year. Villagers reported how trees and vegetation along the river, which earlier were a protection against riverbank erosion, had been uprooted and pulled away, leading to further erosion every year. We were shown the remnants of two concrete bridges, which had been destroyed by the floods, along with four local dams used for irrigation purposes. The canals and pipes that connected them to the fields had also been damaged or flushed away. ${ }^{8}$

Also the upstream villages were affected by the heavy rains. In 2011, they caused landslides in Pang Yang village. Interviewees report that eight households lost part of their maize land due to landslides, which also damaged the forest and flushed away irrigation pipes ${ }^{9}$. The same year, the Mae Larn Noi village headman was killed in a landslide, which also destroyed his house.

In both Doi Phu Kha National Park and the Forest Reserves of Om Koi District, flash floods and landslides have uprooted trees in, what respondents have identified as healthy forests. Interviewees in all villages, as well as the government staff interviewed claim that the force of flash floods experienced the past decade is a new phenomenon. There have been flash floods before 2004, but not with the power to uproot trees and erode the riverbanks in the manner of the recent experiences, as described by our respondents ${ }^{10}$. The effect of flash floods in Om Koi district have also been studied and documented by Manuta et al. (2006). In our interviews with staff of the Watershed Management Unit (WMU) and National Park officials, they claim that there has not been any decrease in forest cover; thus refuting the argument that the increased force of flash floods is due to changes in forest cover. Instead they report observations of higher concentrations of rain i.e. an increased volume of rain at a single point in time. The WMU staff in Om Koi further explains that the rainfall can be very local. Intense rain in a limited area can cause flash floods affecting only a few villages, at that point in time. The WMU monitors rainfall quantities in order to be able to alert villages regarding the danger of imminent flash floods and landslides when rainfall reaches 90-100 mm in a day. The villages Mae Larn Noi and Soplarn also have their own monitoring of rainfall quantities. When the rainfall reaches $90 \mathrm{~mm}$ in a day, the Mae Larn Noi village headman explained that he calls all the villagers to gather in front of the Church, which is seen to be the safest place in the village.

Apart from the increased concentration of rainfall, the interviewees in all villages claim that the weather has become increasingly unpredictable, with temperature extremes, (both hot and cold) longer dry periods, and more variable rainfall. In Om Koi district the unpredictability of the rains was

\footnotetext{
${ }^{7}$ Interviews and group discussions May 2012

${ }^{8}$ Interviews with villagers in November 2012. The interviewees' stories could partly be verified by observation. We could see the remnants of the bridges and dams, still lying on the riverbanks. Between the water and the river bank, there were areas of stone and sand, 10-20 meters wide, indicating how the flash floods had pulled away soil, and deposited stone it its place.

${ }^{9}$ Interviews and group discussion in Pang Yang September 2012 and November 2012.

${ }^{10}$ Interviews in Mae Larn Noi village November 2012
} 
exemplified with the 2012 rains, which continued way into December ${ }^{11}$, instead of ceasing late October as per normal, (see graph over rainfall data in Chiang Mai province, in appendix). Villagers reported that the prolonged rainfall constrained the harvesting and drying of the hill rice, leading to mold and quality loss. In 2011 the rains were reported to have come so early, that farmers in Mae Larn Noi village were unable to burn their fields, which is their way of preparing the hill land for cultivation of rice and vegetables. They could not rotate cultivation that year, with consequences for soil fertility and harvest. Later in the same year there was drought, which further reduced harvest ${ }^{12}$.

\subsection{Vulnerability in context of agriculture development policies}

This section presents our findings regarding the perceptions of villagers and government staff on their vulnerability to climate related hazards and stress and how this is influenced by policies and institutions in agriculture development.

Villagers in all sites explained that livelihoods have changed radically in the past 20 years. Roads, accessible by car and motorcycle, have been constructed, and with the roads came the opportunity for cash crop development. Most interviewees expressed that their livelihoods have improved since the introduction of cash crop production, but there were also expressions of ambivalence regarding the developments. Mr. S in Pang Yang village expressed it as: "Now we need money for fuel, electricity bills, allowances for food and lodging for our children attending school outside the village. The household economy is now dependent on the income from the cash crop”. At the same time, many households expressed concern about problems connected with this production. Farmers interviewed in Pang Yang village were concerned about the conditions of maize production. They explained that maize is grown on land accessible from the road, and some of this land has a high degree of slope (over 50 degrees) and is stony, with thin layers of top soil. The landslides of 2011 have alerted farmers to the problems that heavy rains can cause under such conditions. It was argued by farmers, NGO staff, as well as by local government staff ${ }^{13}$, that the use of herbicides appears to further increase the risk of erosion and landslides, due to a reduction in roots binding the soil. A farmer showed us the difference between soil treated with herbicides, and other soil, where the former was loose, not holding together. Whether this is the general trend, and whether the observed results can be actually traced back to the use of herbicides needs to be further studied and is outside the scope of this paper. Some interviewed farmers argued that, prior to the establishment of the National Park, they would never have cultivated land under such conditions. They are concerned that they cultivate the maize without fallow, but see no alternative. Since the agreement regarding which land Pang Yang village has access to, the fallow periods in cultivation has been reduced from previously 7-15 years, to presently 3-5 years for the hill rice and no fallow for maize ${ }^{14}$. The interviewed farmers are concerned that fallow periods are too short for the land to recover fertility.

Farmers in the focus group discussion also explained to us that, after the establishment of the National Park, the government's Watershed Management Unit (WMU) organized the planting of trees on 160 hectares of Pang Yang village land, further reducing the land available for rotation of crops. Villagers tell us that they took active part in planting the trees, unaware of that this meant that they lost that land. The area is now under the management of the WMU and is inaccessible to the villagers.

Interviewed farmers suggested that their earlier practices of rotational agriculture, focused production on small plots surrounded by forest, were not as exposed to heavy rains and strong winds. Thus, they argue that the segregation of forest and cultivated land is increasing the damages caused by heavy rains,

\footnotetext{
11 The authors experienced this continuous raining in December, as it happened during our fieldwork.

12 Interviews and group discussions October and November 2012

${ }^{13}$ Interviews in May and September 2012 with villagers, staff of Raks Thai Foundation and the Phu Ka sub-district chairman.

${ }^{14}$ Interview with Pang Yang village head, Raks Thai staff, and group discussion with villagers September 2012.
} 
both for themselves and communities downstream.

Official agricultural policy is often formulated for the country as a whole, not differentiating between different geographical areas, which can lead to unintended consequences for land use in upland communities. Staff of Nan province departments ${ }^{15}$ (both agriculture and forestry) commented on the unfortunate consequences of national government policies of generalized promotion of hybrid maize cultivation for the fodder industry. Maize cultivation is widespread in Nan province, although most of the cultivated land is steeply sloping, and at risk of erosion during heavy rains (Thailand Environment Institute 2011). The government officers maintained that a zoning policy should be adopted, with different approaches taken for areas with steep slopes. The agricultural officer explained to us that production of maize, rice and cassava are covered by a government income-guarantee system, which compensates farmers for the production costs in the case of harvest loss or market slump. However, few farmers in Pang Yang actually benefit from this scheme, because it requires farmers to register their crop with the district authorities before the season, and marketing has to be done through the state depots, which are cumbersome practices for remote villages. One farmer explained that he had tried to register, but arrived in the district town when the office was closed, and he did not try again. However, the compensation scheme still contributes to indirectly legitimizing maize production, according to interviewees. The interviewed province-level extension official commented that the government's service programs no longer promote the production of maize on steeply sloped land, but that there is a lack of other realistic alternatives for areas like Pang Yang. In general, he believed firmly in the potential of rubber cultivation as an alternative, but he also explained that such an option is suitable only in areas with a lower elevation and smaller gradient, as compared to in Pang Yang.

Farmers in Hua Nam, downstream of Pang Yang express concern about the perceived increase in sedimentation that the river brings, which clogs up the dam, and the irrigation system. They blame the maize cultivation of Pang Yang village on the slopes above. However an NGO staff suggests that the road construction may be a larger cause of the release of sediment. Wilk et al. (2001) points at how evidence suggests that land fragmentation, land-use changes and road construction may have an interactive effect on local hydrology in Northern Thailand.

Similar to Hua Nam village, the downstream village of Soplarn (Om Koi district), has less focus on hill rice and have their main source of rice for subsistence consumption from paddy land on the riverbanks. The paddy land in Soplarn village used to be a source of wealth and farmers are better-off, as compared to in Mae Larn Noi village, upstream. However, the interviewed farmers expressed worries, with the flash floods 2004 and 2010 in mind, that food security from paddy rice cultivation was at risk ${ }^{16}$. Some farmers said that they have returned to slope land cultivation, (land, which they previously decided to leave for forest regeneration) to compensate for the loss of paddy land.

Threats to cash crop production are different in Om Koi district, as compared to in Pua district, and are connected with crop disease, rather than erosion. The interviewed farmers reported having persistent diseases on their tomato crop in 2011-2012, and many of the farmers in Mae Larn Noi village said that they have debts to the tomato traders of as much as 100,000 baht (approximately 3300 USD) ${ }^{17}$. Some farmers suggest that the crop disease is related to insufficient fallow periods (two-three year rotations). Other farmers suggest that the plant diseases are consequences of too much rain and higher temperatures. The village head said that he had reported the problem to the District Extension Centre, but that they had not been able to get any advice from the extension services regarding what to do about the tomato disease. According to the village head, the extension services only paid attention to issues concerning paddy rice

\footnotetext{
15 Interviewed May 2012

16 Interviews November 2012

17 It is generally the same tradesmen who lend farmers the production inputs including seeds, fertilizer, and pesticides, deducting the loan when buying their harvest. . The tradesmen also provided agriculture advice and generally introduce variety brand of chemical and seed to farmers.
} 
and low land crops. The NGO staff explained to us that, as the government policy is to reforest the slope land, the government services are reluctant to give advice, or in other ways support, agriculture on slope land fields.

Several farmers in Soplarn village expressed their desire to produce maize instead of tomatoes. However, maize cultivation is currently banned in Om Koi District, because, as the head of the District Administration explained, the district government does not wish its landscape to become like that of Nan Province. However, the farmers of Soplarn village claimed that the situation in their area would be different, since their land is less steep and they have no intention of expanding their fields into forest areas.

Lack of rural credit is also a barrier for farmers wanting to switch to alternative livelihoods. Few of the interviewed farmers had accounts in the Bank for Agriculture and Cooperatives. The bank usually requires formal land title documents to give credit, which the upland farmers do not have. Many farmers had thus taken informal loans from traders, relatives or from the village funds to invest in commercial production. Losses in production lead to difficulties in paying the debts and sometimes 'tied' the farmers into a relationship with the trader, which meant that they had to continue producing the same product, like tomatoes, in order to pay back to the trader, as explained to us by the concerned farmers and the village headman.

\subsection{Scenario discussions: Adaptation for disaster risk reduction}

This section presents fieldwork results regarding the perspectives of villagers and government staff regarding options for adaptation and risk reduction and the perceived institutional challenges and opportunities for adaptation.

The FORIN scenario analysis was conducted to understand villager's perspectives regarding options for adaptation and disaster risk reduction under two climate change scenarios: 1) an increase in temperature by one-two degrees, with hotter and dryer summers; 2) an increasing frequency of heavy rains. The villagers discussed the expected impact of these scenarios on the environment, agricultural production and human health. The scenarios build on the experiences that they already have, with the expectation that it may continue, and get worse, during the coming decade.

They then discussed possible means of disaster risk reduction and climate change adaptation, and their expectations for the kind(s) of support necessary to implement these adaptive measures. Villagers perceive the following to be viable DRR and CCA options: i) forest regeneration and management of forest resources, to allow for food- and income generation; ii) improving agricultural land use including the establishment of terraces for paddy fields with irrigation; iii). Identifying alternative sources of income generation; (see table in appendix 1 for detail).

Perspectives on what kind of changes would be required for adaptation and disaster risk reduction were also sought from local government staff.

\subsection{Costs of Microinsurance: Is it affordable?}

Scientifically, the causal relationship between forest cover and hydro-meteorological hazards is a topic of considerable debate within the existing literature. Thus far, there is conflicting evidence as to the impact of land-use and land-cover change on such hydrological variables as local rainfall, stream-flow, run-off, and water balance (Bruijnzeel 2004; Cuo et al. 2008))

All the villages, have responded to floods and landslides threatening their settlements, by deciding to let forest regenerate on land previously used for agriculture on the slopes above their village. In Pang Yang village, 9 households had pioneered giving up agriculture on 12 hectares of slope land, and other households are gradually following their example. One of the farmers who had contributed land explains that the regenerated forest area becomes community forest. However, it is expected that if individual 
households plant additional trees or plants of economic value, e.g. coffee in the forest, they would have rights to the harvest of those products on the land that the household contributed. So far this is not practiced, but in the group discussion regarding adaptation options, it was suggested as a way forward.

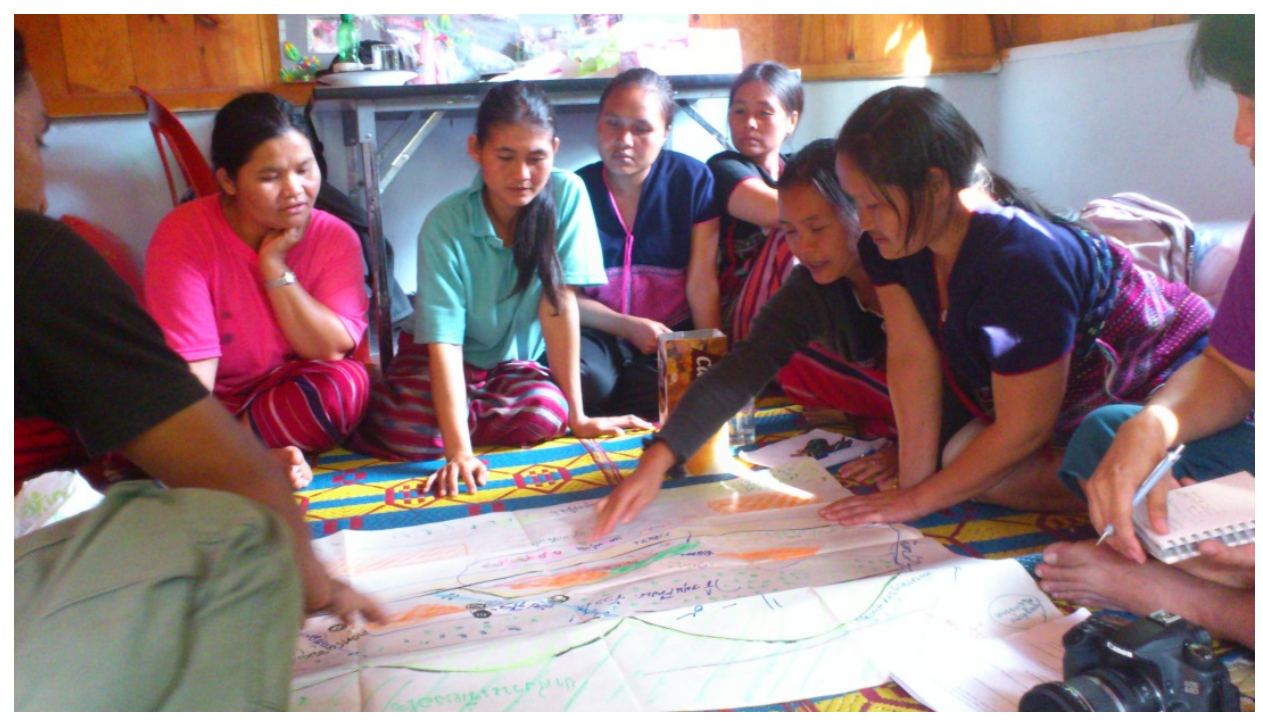

Figure 2: FORIN session with women’s group in Mae Larn Noi village.

Similarly, the villages in Om Koi district, Mae Larn Noi and Soplarn, had also recently taken decisions in village meetings to let part of their land regenerate forest permanently - i.e to take it out of the crop rotation system, according to the village headmen and focus group discussions.

Unfortunately the Thai government has so far not been able to formally recognize community forests as a legal form of land tenure, even though community forest management is wide spread in the country. Negotiations within the government regarding the delineation of regulations and tenure status have been ongoing for decades, but the Community Forest Act has never been passed by Parliament (Forsyth and Walker 2008). NGO staff explain this as due to differences in the perspectives regarding the best way to protect the country's forested areas. The Royal Forest Department (RFD) used to represent a perspective that forest protection cannot allow for any human activity. However, this perspective has been challenged, also from within the RFD, by its Community Forest Division (Ganjanapan ed. 2000). In September 2013, the RFD and the Centre for People and Forests signed a MoU to cooperate in supporting the development of community forest management (RECOFTC 2013). The government staff at district and province level that we interviewed in our research were also positive towards community forest management. For example, according to province-level government staff in both the forest and agriculture sectors, in Nan Province, it would be easier to expand forest cover if farmers were allowed to manage forest, and plant economically valuable species for their own benefit in the forest. Also staff of the Doi Phu Ka National Park suggested that an official policy recognizing the role of villages as "co-managers" of forests would be helpful. They explained that given the limited official manpower, input from villagers could be useful to help protect the forest. The staff added their view, that the villagers are, in practice, already playing such a role, since they are usually in the forest and likely to notice any illegal activities.

\subsection{Improved Agricultural Land Use as DRR and CCA}

At present slope land cultivation has two purposes for the upland farmers. The first is the cultivation of 
hill rice for food. Interviewed farmers explained that this is gradually being replaced by the construction of terraces and purchase of pipes for irrigation to enable farmers to grow paddy rice. However, hill rice cultivation still represents the major source of food for subsistence in the two upstream villages (Pang Yang and Mae Larn Noi). The farmers further explain that the hill rice is intercropped with vegetables, which are of great importance for household nutrition needs. Farmers in a group discussion in Mae Larn Noi expressed that they would happily give up rotational agriculture on sloped land if they were to receive support to replace hill-rice cultivation with paddy rice on terraces. This, they said, is due to the fact that hill-rice farming is very labor-intensive, requiring farmers to walk long distances and work on steep slopes. So far only 17 of the 55 households in Mae Larn Noi have paddy terraces close to small streams. To expand terraced land would take much larger investments, because of steeper slopes and further from water sources. In Soplarn village, most of the households have paddy land, reflecting the favourable conditions on the banks of major rivers.

The staff of the Mae Hat Watershed Management Unit (WMU) in Om Koi explains that the WMU has a government budget to provide each of 44 households per year with 10,000 baht to make terraces, provided that they give up the cultivation of sloped land in the proportion 4:1 (four plots of rotation land in exchange for one plot of terraced land) ${ }^{18}$. However, 44 households is a small percentage of the upland farmers in the district. The village head of Mae Larn Noi expressed disappointment that his village had not yet been able to secure such support. An additional constraint is that the support is sufficient only for the construction of terraces and not for the irrigation infrastructure. In Soplarn village, five households had received the WMU support. A focus group discussion suggested that dozens of households are interested in expanding terraced cultivation further from the river, to compensate for their loss of paddy land during flash floods.

In Nan, the Provincial Administrative Organisation (PAO) allocates budget to support the conversion of slope land to terraces by providing tractor power and pipes for irrigation (CODI 2009). The support is managed by the $\mathrm{WMU}^{19}$. Pang Yang village had received such support as a compensation for their loss of agriculture land to tree planting a decade ago. However, some farmers said they had not yet been able to secure pipes for irrigation, and could not yet cultivate crops on the terraces.

The village discussions on adaptation needs also addressed the issue of water scarcity during the dry season. Many of the interviewees had noted decreasing water levels in the streams during dry season. In Soplarn village, farmers found the water shortages puzzling, as they claimed that there had been no changes in forest cover or land use upstream during the past decade. There were divided opinions among villagers regarding the risk of future water shortages. A common perception was that the water would be enough if only they had satisfactory infrastructure for water storage and irrigation. However, especially the village heads have been more concerned, asking for support with analysis regarding changing rain patterns and availability of water.

Lebel, L. et al. (2009) point at the need for attention to the consequences of expanding irrigation: "Changes in flood regimes may interact with agriculture decision-making in complex ways as farmers try to adapt to changing risks of water shortage and excess, and thereby alter runoff, groundwater recharge and return flows to rivers from their fields”.

The second purpose of slope land cultivation is for income generation. In Pang Yang village, the farmers told us that they recognize the risk of erosion involved in hybrid maize production on the slopes. The village meeting, which discussed adaptation to climate change scenarios ${ }^{20}$, ranked finding alternative sources of income as their number one priority for adaptation and development. Farmers claim that it is

\footnotetext{
18 Interview December 2012

${ }^{19}$ According to interview with an officer of the Agriculture Department of Nan Province (September 2012)

${ }^{20}$ In Pang Yang village the scenario discussions were organized in cooperation with Recoftc - The Regional Centre for People and Trees, Bangkok.
} 
difficult for them to get support for developing alternative ways of income generation. Staff of the District Agriculture Extension services in Pua, explained to us that they do not have the mandate for advising on slope land agriculture in watershed forest protection areas. However, there is some extension advice available from 'The extended Royal Project' in Pang Yang village, from the NGO, Raks Thai Foundation, and from the private traders of cash crops.

A successful farmer in Pang Yang showed us his commercial vegetable production on terraces; while other farmers expressed that they have too limited knowledge of technologies and markets to dare to invest. In the scenario discussions, many farmers asked for support to develop coffee production. Some of them had tried coffee before, but at the time, there was no market for their coffee. Now a newly established roasting industry in the district had increased their interest in trying again. They also had other ideas for indigenous species of trees that they could develop in the forest for income generation from fruits and bark. Likewise, in Mae Larn Noi and Soplarn villages, farmers put their hopes to more income generation from forest based production like coffee, fruit trees, vegetables and forest tea. They were hoping to develop such agro-forestry production on the slope lands around the village and thereby develop a type of land use, which could satisfy both livelihood needs and needs for erosion control. The NGO Raks Thai Foundation had supported some farmers to develop such models in Mae Larn Noi. However, the District Extension services did not have that kind of activities. An extension officer explained that agro-forestry is not a recognized land use category.

Soplarn village has been allocated teak forest for protection. This could become a valuable source of income in future, but the villagers are not clear on whether they will be allowed to get selective harvesting rights, as this would require recognition of their tenure rights to the forests.

\subsection{Non-farm income to reduce dependency on agriculture}

Women in Soplarn village have been supported by a Royal project to market their weaving of textiles. Mae Larn Noi village is hoping that they could get similar support. Most of the women in these villages weave for domestic needs, and have previously not marketed their products. The Royal Project buys the textiles from the women to sell through their network.

At the feedback meeting in Hua Nam village, supplementary sources of both food and income were discussed. The villagers expressed concern over the frequent damage to their irrigation dam, threatening dry season production of cash crops. In the longer time perspective they are concerned that changing climate conditions may cause increasing problems for paddy production. The farmers suggested that more attention should be paid to the development of vegetable and fruit gardens in backyards and on hill land. Other suggestions included developing eco-tourism, planting groundnut and beans to replace some paddy, and reconstruction of the reservoir. As Hua Nam village is relatively close to the district town, some farmers sold residential land to urban households who wanted to live in the rural areas. Hua Nam villagers also highlighted the speed of transition, as the young people in the village were not so interested in farming, but were increasingly seeking urban livelihoods.

\section{CONCLUSION AND POLICY IMPLICATIONS}

The FORIN investigation was conducted to identify socio-economic and institutional drivers of climate related disasters in upland communities in Northern Thailand. The study focused on the perceptions of villagers regarding changing weather patterns, local livelihood options and access to resources, including institutional support. Interviews in the four villages suggest that upland villagers perceive an increased exposure and vulnerability to climate related hazards and stresses. This increase is perceived to be related to a shift to intensive cash crop mono-culture, insufficient extension support for 
slope land farming, and forest policies limiting livelihood options.

The top-down forest- and agricultural polices appear to have neglected the livelihood needs in the studied communities, resulting in reduction of land available for agriculture, and shortening of agricultural rotation cycles, as compared to 20 years ago. Interviewees describe how cash crop production has improved their livelihoods, but, in combination with the perceived unpredictability of the rains, the villagers suggest that there is an increasing risk of erosion and landslides, due to the intensified land-use, i.e. cultivation without fallow and with agro-chemicals.

The complex interaction between institutional drivers of vulnerability and climate-related disasters supports the FORIN disaster risk reduction hypothesis: "[new] and more probing research and understanding of the reasons for growth in public vulnerability and wider exposure would enable and stimulate improved disaster risk reduction (IRDR 2011).” The study responds to the FORIN hypothesis that "a more integrated and participatory research is required to yield more useful and effective results regarding disaster risk reduction”. Based on the fieldwork at village and local government level, the study finds that top-down agriculture- and forestry policy appears to neglect the livelihood needs of forest dependent communities, reinforcing their vulnerability to natural hazards such as flash floods and landslides. Addressing these multilayer and cross-sectoral drivers of disaster risk, require more integrated development policies, which can cater for the livelihood needs, environmental protection and disaster risk reduction of forest dependent communities. Based on the results of the study, we argue that disaster risk reduction cannot be the responsibility of a single government agency like the Department of Disaster Preparedness and Mitigation, (DDPM) but needs to be included in the responsibilities of all development sectors. The DDPM can control activities in direct relation to the disaster, like early warning, preparedness and compensation. But the disaster risks linked to issues of land use need to be addressed in the sectors of agriculture, forestry, water management, micro- finance etc.

The study found a high awareness of climate related risks at village level, as well as a willingness of farmers to adapt their practices in order to reduce risk. Our field results suggest that farmers come to a different conclusion, as compared to policy makers, regarding how to reduce risk. Forest protection policies are implemented partly as a measure to mitigate climate related hazards. However, it implies a segregation of agriculture and forest, which has led to intensive cultivation on the non-forest slope land. Interviewed farmers suggest that the present agriculture is more exposed to challenging weather conditions, as compared to previous rotational practices in the forest. In order for villagers to be able to re-orient their livelihood strategies the results point towards the need for policies and institutional approaches that enable villagers to shift resources from intensive cultivation of marginal areas to a more integrated agro-forestry land use. Many of the interviewed farmers, village leaders and government staff suggest policies to support forest communities in making a living from the forest, and to develop integrated forms of agro-forestry, in order to reduce open and exposed agricultural land, thereby reducing the risk of losses to flash floods, erosion, and landslides. They argue that an agro-forestry landscape is less exposed to disaster and climate-related risk, as compared to a landscape divided between forested areas and agricultural production on steep slopes.

Government programs support the gradual replacement of slope land cultivation of hill rice with irrigated paddy rice on terraces. However, there is a perceived lack of government support for farmers to develop alternative, less risk prone, income generation strategies. Market driven cash crop development has resulted in mono-culture of cash crops (maize and tomato) with high levels of chemical inputs, apparently ill-suited to slope land conditions. Interviewees suggest that extension services and credit systems are not adapted to address upland farmers, who lack formal land tenure rights.

Resilience requires buffers against potential disturbances such as extreme weather and agricultural market shocks (Cabell and Oelofse 2012). At present the household economy in upland communities is very reliant on mono-culture of cash crops on slope land, with few alternative sources of food and income as buffer resources. Villagers see production on irrigated terraces as a way forward. However, the use of 
rotational land is an important buffer to fall back on when the main crops fail. Non-timber forest products also continue to have a buffer function, as well as animal husbandry and remittances from family members working in urban centers.

In this paper, we have focused on the common denominators in institutional conditions that were perceived by villagers and local staff to be constraining household- and community options of disaster risk reduction. These include limited access to agricultural land and forests for livelihood needs, limited access to extension services and limited support to re-orient production development away from hazardprone areas. The third FORIN hypothesis calls for attention to differentiated vulnerability: "Responsibility for the continued growth in vulnerability and exposure is locally specific and diffuse over individuals, organizations, jurisdictions, and over time”. These aspects will be discussed in a coming paper.

The interaction between the socio-economic changes and climate related hazards requires further interdisciplinary studies, including the assessment by agriculture and forestry engineers, conservation scientists, hydrologists and climatologists together with social scientists and community residents to achieve more detailed understanding of the interaction of social and natural drivers of disaster risk in the region.

\section{REFERENCES}

Adger, N. and Brown, K. (2009) Vulnerability and Resilience to Environmental Change: Ecological and Social perspectives. In: Castree, N. et al. (eds) A Companion to Environmental Geography. London, Blackwell: 109-122.

Bruijnzeel, L.A. (2004) Agriculture Hydrological functions of tropical forests: not seeing the soil for the trees? Ecosystems and Environment 104: 185-228

Cabell, J.F. and Oelofse, M. (2012) An Indicator Framework for Assessing Agro-ecosystem Resilience. Ecology and Society 17(1):18.

Creswell, J. (1998) Qualitative Inquiry and Research Design. London, Sage.

Community Organizations Development Institute (2009) Summary of Seminar on "The Role of Local Administrative Organisation to the Agricultural and Resettlement Lands". Available from: <http://www.gotoknow.org/posts/306104>. [13 April 2015]. (in Thai)

Cuo, L. Giambelluca, T.W. Ziegler, A.D. and Nullet M.A. (2008) The roles of roads and agricultural land use in altering hydrological processes in Nam Mae Rim watershed northern Thailand. Hydrological Processes 22 (22): 4339-4354.

Cutter, S. Osman-Elasha, B. Cambell, J. Cheong, M. McCormick, S. Pulwarty, R. Supratid, S and Ziervogel, G. (2012) Chapter 5: Managing the Risks from Climate Extremes at the Local Level. In IPCC 2012. Managing the Risks of Extreme Events and Disasters to Advance Climate Change Adaptation. Cambridge University Press: 291-338.

Davies, M. Oswald, K and Michell, T. (2009) Climate Change Adaptation, Disaster Risk Reduction and Social Protection. IDS WP 320. Available from: < http://www.ids.ac.uk/publication/climate-changeadaptation-disaster-risk-reduction-and-social-protection-complementary-roles-in-agriculture-andrural-growth>. [13 April 2015].

Forsyth, T. and Walker, A. (2008) Forest Guardians, Forest Destroyers: The Politics of Environmental Knowledge in northern Thailand. University of Washington Press.

Integrated Research on Disaster Risk (2011) Forensic Investigations of Disasters: The FORIN 
Project (IRDR FORIN Publication No. 1). Beijing: Integrated Research on Disaster Risk. Available from: http://www.irdrinternational.org/wp-content/uploads/2012/06/FORINREPORT web.pdf [7 May 2015].

Ganjanapan ed. (2000) Community Dynamic to Managing of Natural Resources: Paradigm and Policy. Bangkok: Thailand Research Fund. Bangkok (in Thai)

Lebel, L., Foran, T., Garden, P., and Manuta, J.B. (2009) Adaptation to climate change and social justice: challenges for flood and disaster management in Thailand. In: Ludwig, F. et al. (eds) Climate Change Adaptation in the Water Sector. London, Earthscan:125-141.

Manuta, J., Khrutmuang, S., Huaisai, D. and Lebel, L. (2006) Institutionalized incapacities and practice in flood disaster management in Thailand. Science and Culture 72:10-22.

Miles, M. and Huberman, M. (1994) Qualitative Data Analysis: A Methods Source Book. London, Sage.

Ministry of Interior. (2013) Ministry of Interior Newsletter Vol 13/2556. Public Relation Division. Available from: <http://www.pr.moi.go.th/image/mtnews/2556/13-56.pdf> . [13 April 2015]. (in Thai).

Naruchaikusol, S., Beckman, M. and Mochizuki, J. (2014) Disaster Response and Adaptive Capacity of Upland Communities in the Face of Increasing Climate Risk. A Discussion of Changing Livelihoods, Land Use, and Natural-Resources Management in Northern Thailand. IRDR International Centre of Excellence - Taipei Technical Report No.1 Available from <http://www.start.org/download/2014/aiirdr/naruchaikusol-forin-projectreport.pdf>. [13 April 2015].

Nelson, D., Adger, N. and Brown, K. (2007) Adaptation to Environmental Change: Contributions of a Resilience Framework. Annual Review of Environment Resources 32:395-419.

Raks Thai Foundation. (2008) Raks Thai Foundation Annual Report 2008. Available from: $<$ www.raksthai.org/files/media/mb0044 1.pdf > . [13 April 2015]. (in Thai).

RECOFTC [The Center for People and Forest]. (2013) Recoftc and the Royal Forest Department of Thailand sign MoU. Available from: < http://www.recoftc.org/news-and-features/recoftc-and-royalforest-department-thailand-sign-mou>. [23 September 2013]

Thailand Environment Institute. (2011) Summary Report Sub-Global Assessment (SGA) for Nan Province, Thailand. Available from:

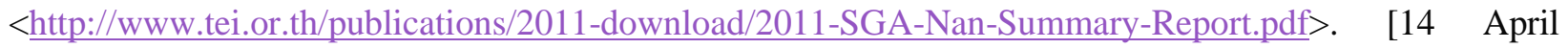
2015]

UNISDR [United Nations Office for Disaster Risk Reduction]. (2009) Gobal Assessment Report on Disaster Risk Reduction: Risk and Poverty in a Changing Climate Invest Today for a Safer Tomorrow. Available from: < http://www.unisdr.org/we/inform/publications/9413 $>$ [13 April 2015].

White, G., Kates, R., Burton, I. (2001) Knowing better and losing even more: the use of knowledge in hazards management. Environmental Hazards 3: 81-92

Wilk, J., Anderson, L., and Plermkamo, V. (2001) Hydrological impacts of forest conversion to agriculture in a larger river basin in northeast Thailand. Hydrological Processes 15 (14): 2729-2748.

Wisner, B., Blakie P., Cannon, T., and Davis I. (2004) At Risk: Natural Hazards, People’s Vulnerability and Disasters. London, Routledge. 


\section{Appendix 1: Scenario Analysis Summary}

Table A1. Expected impact of a continuation of current observations of climate change during the coming decade (average $1-2$ degrees Celsius increase and rapid weather changes within the same day (hot/rain/cold)) and adaptation options

\begin{tabular}{|c|c|c|c|c|}
\hline & Agriculture & $\begin{array}{c}\text { Natural Resources } \\
\text { Management and } \\
\text { Livelihood }\end{array}$ & Adaptation Options & External Support Needs \\
\hline $\begin{array}{l}\text { Positiv } \\
\text { e }\end{array}$ & $\begin{array}{l}\text { Increased rice/maize } \\
\text { yield (more } \\
\text { photosynthesis) } \\
\text { Faster maize } \\
\text { growth }^{* \mathrm{M}} \\
\text { Faster tomatoes } \\
\text { growth }{ }^{* \mathrm{~S}} \\
\text { Faster and easier to } \\
\text { burn fields (in } \\
\text { preparation for the } \\
\text { next season) } \\
\text { Easier to dry rice } \\
\text { following the } \\
\text { harvest }\end{array}$ & $\begin{array}{l}\text { Increased tree growth in } \\
\text { forests }{ }^{* B} \\
\text { Increased wood sources } \\
\text { for fuel and cogon grass } \\
\text { for roofing }{ }^{* \mathrm{M}}\end{array}$ & $\begin{array}{l}\text { Increase use of } \\
\text { chemicals/biological } \\
\text { alternatives for pest } \\
\text { control }{ }^{* \mathrm{P}, \mathrm{B}, \mathrm{M}, \mathrm{S}} \\
\text { Drought tolerant rice } \\
\text { and maize } \\
\text { Improve water } \\
\text { management for fish } \\
\text { ponds and cultivate less } \\
\text { sensitive species }{ }^{* \mathrm{P}} \\
\text { Reforest/expand forest } \\
\text { fire protection roads }{ }^{* \mathrm{P}} \\
\mathrm{B}, \mathrm{M}, \mathrm{S}\end{array}$ & $\begin{array}{l}\text { Extension and market } \\
\text { advice for alternative } \\
\text { crops }{ }^{* \mathrm{P}, \mathrm{B}, \mathrm{M}, \mathrm{S}} \\
\text { Research on drought } \\
\text { tolerant seed } \\
\text { varieties }{ }^{* \mathrm{P}, \mathrm{B}, \mathrm{M}, \mathrm{S}} \\
\text { Loan schemes for } \\
\text { investment in } \\
\text { agriculture }{ }^{* \mathrm{P}, \mathrm{M}} \\
\text { Survey and maintain } \\
\text { water storage tanks and } \\
\text { build more mini- } \\
\text { reservoirs } \\
\text { Support for fish }\end{array}$ \\
\hline $\begin{array}{l}\text { Negati } \\
\text { ve }\end{array}$ & $\begin{array}{l}\text { Increased number of } \\
\text { pests, insects and } \\
\text { mice }{ }^{* \mathrm{P}, \mathrm{M}, \mathrm{S}} \\
\text { Water } \\
\text { shortage/increased } \\
\text { water need } \\
\text { R,M, S } \\
\text { Reduced } \\
\text { germination due to } \\
\text { drought/high } \\
\text { temperature } \\
\text { Reduced fruit yield } \\
\text { (e.g. Lychee) } \\
\text { Fish deaths from } \\
\text { warmer water in the } \\
\text { fish ponds } \\
\text { Da,S } \\
\text { Damaged vegetable } \\
\text { crops (e.g. cabbage) } \\
\text { Decreased rice } \\
\text { yield }{ }^{* M}\end{array}$ & $\begin{array}{l}\text { Increased incidence of } \\
\text { forest fires }{ }^{* \mathrm{P}, \mathrm{M}, \mathrm{S}} \\
\text { Reduction of some } \\
\text { NTFPs }{ }^{* \mathrm{M}, \mathrm{S}} \\
\text { Limited water for } \\
\text { household consumption } \\
\text { and farming }{ }^{* \mathrm{P}, \mathrm{M}, \mathrm{S}} \\
\text { Increased seasonal or } \\
\text { permanent migration to } \\
\text { towns or cities for off- } \\
\text { farm jobs }{ }^{* \mathrm{M}} \\
\text { More time spent on farm } \\
\text { work (watering and pest } \\
\text { control) }\end{array}$ & $\begin{array}{l}\text { Home gardens for own } \\
\text { consumption }{ }^{* \mathrm{~B}} \\
\text { Weather forecasts for } \\
\text { crop planning }{ }^{* \mathrm{~B}, \mathrm{M}} \\
\text { Switch from rice to } \\
\text { groundnut or beans } \\
{ }^{* \mathrm{~B}} \\
\text { Improve irrigation } \\
\text { system }{ }^{* \mathrm{~B}, \mathrm{P}, \mathrm{M}, \mathrm{S}} \\
\text { Protect local water } \\
\text { catchment areas*S } \\
\text { Forest awareness } \\
\text { working groups to } \\
\text { monitor forest fires }{ }^{* \mathrm{~S}, \mathrm{M}} \\
\text { Agro-forestry }{ }^{* \mathrm{P}, \mathrm{M}}\end{array}$ & $\begin{array}{l}\text { Alternative water } \\
\text { sources (e.g. } \\
\text { underground water) }{ }^{* \mathrm{P}} \\
\text { Weather forecasts }{ }^{* \mathrm{~B}, \mathrm{P}, \mathrm{M}, \mathrm{S}} \\
\text { Forest fire monitoring } \\
\text { and fire protection }{ }^{* \mathrm{~B}, \mathrm{~S}} \\
\text { Knowledge of irrigation }_{\text {system improvement }^{* \mathrm{M}}}\end{array}$ \\
\hline
\end{tabular}

Note: *P (Pang Yang); *B (Ban Hua Nam); *M (Mae Larn Noi);*S(Soplarn)

Source: Scenario analysis sessions 
Table A2. Expected impact of a continuation of current observations of climate change during the coming decade (Changing rainfall pattern such as heavy rain in particular areas within a short period) and adaptation options

\begin{tabular}{|c|c|c|c|c|}
\hline & Agriculture & $\begin{array}{l}\text { Natural Resources } \\
\text { Management and } \\
\text { Livelihood }\end{array}$ & Adaptation Options & $\begin{array}{l}\text { External Support } \\
\text { Requirements }\end{array}$ \\
\hline $\begin{array}{l}\text { Positi } \\
\text { ve }\end{array}$ & $\begin{array}{l}\text { Improved water } \\
\text { supplies for terrace } \\
\text { rice and upland rice } \\
\text { irrigation and } \\
{ }^{\text {Comp,B,M }} \text {. }\end{array}$ & $\begin{array}{l}\text { Decreased risk of forest } \\
\text { fires }{ }^{* \mathrm{P}, \mathrm{M}} \\
\text { Increased water } \\
\text { supply }{ }^{* \mathrm{~B}, \mathrm{M}, \mathrm{S}} \\
\text { Increased income from } \\
\text { NTFPs collection (e.g. } \\
\text { mushrooms) }\end{array}$ & $\begin{array}{l}\text { Adjust cropping period } \\
\text { for late rainy season }{ }^{* \mathrm{P}} \\
\text { Build large silos to dry } \\
\text { and store products*P } \\
\text { Grow elephant grasses } \\
\text { against soil erosion }{ }^{* \mathrm{P}} \\
\text { Convert fallow land to }\end{array}$ & $\begin{array}{l}\text { Seedlings (e.g. elephant } \\
\text { grass) } \\
{ }^{*}{ }^{2} \\
\text { Political } \\
\text { acknowledgement of } \\
\text { rotational cropping } \\
\text { practices }^{* \mathrm{P}, \mathrm{M}, \mathrm{S}} \\
\text { Enhance crop yield }^{* \mathrm{P}}\end{array}$ \\
\hline $\begin{array}{l}\text { Negat } \\
\text { ive }\end{array}$ & $\begin{array}{l}\text { Crops damaged by } \\
\text { flash floods, and } \\
\text { fungi }{ }^{* \mathrm{P}, \mathrm{B}, \mathrm{M}, \mathrm{S}} \\
\text { Damage to } \\
\text { agricultural land and } \\
\text { irrigation } \\
\text { systems } \\
\text { Los, }{ }^{* \mathrm{~B}, \mathrm{~B}, \mathrm{M}} \\
\text { soil/erosion (nutrient } \\
\text { and fertilizers) } \\
\text { The inc, } \\
\text { of the water resulting } \\
\text { in reservoir damage. } \\
{ }^{* \mathrm{~B}} \\
\text { Higher risk of hail } \\
\text { damage to } \\
\text { agricultural } \\
\text { products }\end{array}$ & $\begin{array}{l}\text { Landslides affecting } \\
\text { community managed } \\
\text { forest and other forest } \\
\text { areas }^{* \mathrm{P}, \mathrm{B}, \mathrm{M}, \mathrm{S}} \\
\text { Soil erosion and } \\
\text { sediment to stream }{ }^{* \mathrm{P}, \mathrm{M}, \mathrm{S}, \mathrm{B}} \\
\text { Road damage and blocks } \\
\text { from landslides and flash } \\
\text { floods }{ }^{* \mathrm{~B}, \mathrm{P}, \mathrm{M}, \mathrm{S}} \\
\text { Strong wind and storm } \\
\text { damage to houses and }_{\text {crops }^{\mathrm{S}, \mathrm{P}}}\end{array}$ & $\begin{array}{l}\text { Develop a CBDRM plan } \\
\text { and committee }{ }^{*}, \mathrm{M}, \mathrm{S} \\
\text { Monitor } \\
\text { flashfloods/landslides in } \\
\text { ag. areas }{ }^{* \mathrm{~B}, \mathrm{P}} \\
\text { Growing upland rice to } \\
\text { compensate for damage } \\
\text { in paddy fields }{ }^{* \mathrm{~S}} \\
\text { Reforest - Implement } \\
\text { watershed protection } \\
\text { activities }{ }^{*}, \mathrm{P}, \mathrm{M}, \mathrm{S} \\
\text { Build check-dams } \\
{ }^{* \mathrm{M}, \mathrm{S}} \\
\text { Weather forecasts and } \\
\text { local climate knowledge } \\
\text { for crop planning }{ }^{* \mathrm{M}, \mathrm{S}} \\
\text { Regular maintenance of } \\
\text { irrigation system }{ }^{* \mathrm{~S}} \\
\text { Build ponds or wells to } \\
\text { collect rain water }{ }^{* \mathrm{~S}}\end{array}$ & $\begin{array}{l}\text { Agro-forestry }{ }^{* \mathrm{P}, \mathrm{M}} \\
\mathrm{CBDRM}^{* \mathrm{P}, \mathrm{B}, \mathrm{M}, \mathrm{S}} \\
\text { Check dams and } \\
\text { reservoirs }{ }^{* \mathrm{~B}, \mathrm{~S}} \\
\text { Compensation for losses } \\
\text { adequate for recovery and } \\
\text { relief }{ }^{* \mathrm{~B}, \mathrm{~S}} \\
\text { Community reservoirs } \\
\text { and early warning } \\
\text { systems }{ }^{{ }^{\mathrm{M}}} \\
\text { Activities to prevent } \\
\text { damage from flash } \\
\text { floods }{ }^{* \mathrm{~S}}\end{array}$ \\
\hline
\end{tabular}

Note: *P (Pang Yang); *B (Ban Hua Nam); *M (Mae Larn Noi);*S(Soplarn)

Source: Scenario analysis sessions 


\section{Mean Rainfall in Chiangmai (2003 - 2011)}

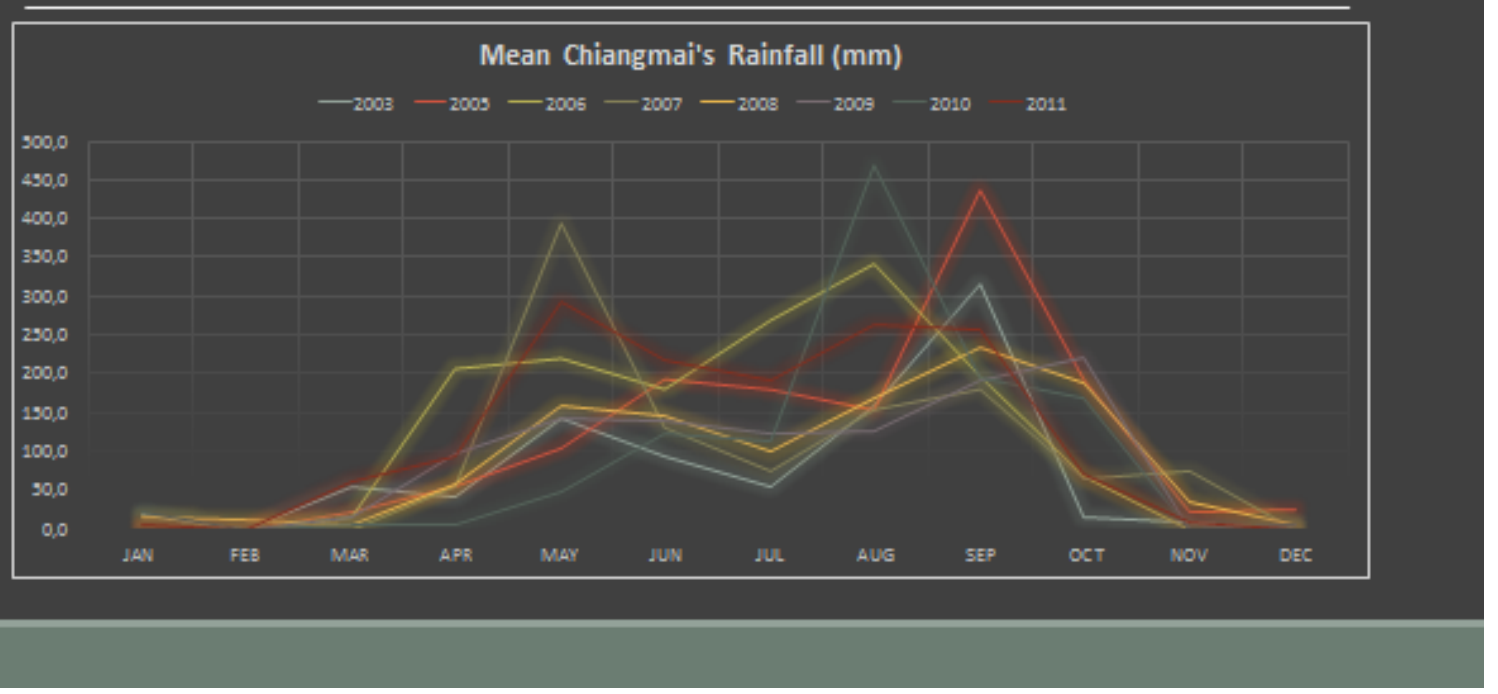

Figure A1. Rainfall in Chiangmai (2003-2011)

\section{Appendix 3: Results from interviews and group discussions May 2012- January 2013}

The numbers the first row represent the number of households interviewed in relation to total households in the village. The numbers on the subsequent rows represent the number of villagers making the remark. All the issues in this table were also brought up by the participants in the group discussions.

Table A3. Interview Results Summary

\begin{tabular}{|l|l|l|l|l|}
\hline \multicolumn{1}{|c|}{ Content } & $\begin{array}{l}\text { Pang } \\
\text { Yang } \\
\text { Village } \\
\mathbf{1 5 / 8 3} \mathbf{~ h h}\end{array}$ & $\begin{array}{l}\text { Hua } \\
\text { Nam } \\
\text { Village } \\
\mathbf{1 0 / 1 4 4}\end{array}$ & $\begin{array}{l}\text { Mae Larn } \\
\text { Noi } \\
\text { Village } \\
\mathbf{1 2 / 4 4}\end{array}$ & $\begin{array}{l}\text { Soplarn } \\
\text { Village } \\
\mathbf{1 5} / \mathbf{2 1 3}\end{array}$ \\
\hline Hh having lost land in flash floods & 4 & 4 & 2 & 12 \\
\hline $\begin{array}{l}\text { Hh claiming that climate related } \\
\text { hazards have become worse the } \\
\text { past decade }\end{array}$ & 11 & 7 & 5 & 13 \\
\hline $\begin{array}{l}\text { Hh reporting damage to their crops the past 3 years, linked } \\
\text { to unusual behavior of rainfall }\end{array}$ & 12 & 5 & 8 & 11 \\
\hline
\end{tabular}




\begin{tabular}{|c|c|c|c|c|}
\hline $\begin{array}{l}\text { Hh suggesting the need for more extension services for } \\
\text { upland cultivation }\end{array}$ & 5 & & 6 & 4 \\
\hline $\begin{array}{l}\text { Hh claiming that they have a shortage of agricultural land, } \\
\text { leading to short rotation periods and } \\
\text { low fertility }\end{array}$ & 12 & & & 3 \\
\hline $\begin{array}{l}\text { Hh suggesting that agriculture chemicals } \\
\text { are causing problems for the environment and their health. }\end{array}$ & 4 & 6 & 2 & 3 \\
\hline $\begin{array}{l}\text { Hh suggesting the need to develop food and } \\
\text { income from the forest and/or agro-forestry. }\end{array}$ & 11 & 3 & 5 & 2 \\
\hline Hh who suggest that support for irrigation is a key issue & 9 & 6 & 5 & 7 \\
\hline $\begin{array}{l}\text { Hh wanting to change production, in order to be less } \\
\text { exposed to environment risk }\end{array}$ & 7 & & 3 & \\
\hline $\begin{array}{l}\text { Hh expressing need for support to development } \\
\text { of production on terraces }\end{array}$ & 13 & & 4 & 6 \\
\hline $\begin{array}{l}\text { Hh who say that they received some kind of disaster } \\
\text { relief after loss of land or crop }\end{array}$ & 5 & 5 & 3 & 10 \\
\hline $\begin{array}{l}\text { Hh mentioning non-timber forest products as a key } \\
\text { livelihood resource }\end{array}$ & 8 & 2 & 7 & 4 \\
\hline $\begin{array}{l}\text { Hh recently having given up agriculture land for forest } \\
\text { regeneration }\end{array}$ & 9 & 2 & 4 & 4 \\
\hline $\begin{array}{l}\text { Hh who express ideas for how to reduce environmental } \\
\text { risk to production and livelihoods }\end{array}$ & 11 & 6 & 5 & 4 \\
\hline
\end{tabular}

Note: The interviews did not all cover the same questions. As they were semi-structured the interviews also depended on which issues the interviewees raised as key concerns. The figures in the table should thus be read as issues raised by the interviewees in response to more open questions. One cannot draw the conclusion that the remaining number of interviewees would have responded negatively regarding these issues. However it gives an indication on household priority issues. 